\title{
ReSEARChArTicle
}

\section{Genetic variability, heretability, correlation co-efficient and path analysis of yield and yield contributing traits in bread wheat (Triticum aestivum L.)}

\author{
MANISHA SAINI AND SHWETA
}

\begin{abstract}
SUMMARY
Genetic variation, heritability, genetic advance and correlation co-efficient studied among the fifty wheat genotypes and were evaluated for eleven quantitative characters viz., days to 50 per cent flowering, days to reproductive phase, days to maturity, plant height $(\mathrm{cm})$, number of reproductive tillers per plant, spike length $(\mathrm{cm})$, number of spikelets per spike, number of grains per spike, grain weight per spike (g), test weight $(\mathrm{g})$ and grain yield per plant $(\mathrm{g})$. All the characters under study showed considerable amount of variability, phenotypic co-efficient of variability was higher than genotypic coefficient of variability. A persual of co-effiecient of variability indicates that PCV and GCV were quiet high for grain weight per spike. Moderate PCV and GCV were recorded in yield per plant, spike length, number of reproductive tillers per plant, number of spikelets per spike and lowest observed in days to maturity, days to 50 per cent flowering, days to reproductive phase and test weight. A high estimate of heritability was found for plant height. High genetic advance was observed for grain weight per spike (28.85g) and minimum in days to maturity (6.88). Genotypic correlation co-efficients were higher than the corresponding phenotypic correlation co-efficients for all the character combinations. Grain yield per plant showed highly positive association ship with days to 50 per centflowering, days to reproductive phase, plant height, spike length, grain weight per spike and number of grains per spike.
\end{abstract}

Key Words : Genetic variation, Heritability, Genetic advance, Correlation co-efficient, Path analysis

How to cite this article : Saini, Manisha and Shweta (2017). Genetic variability, heretability, correlation co-efficient and path analysis of yield and yield contributing traits in bread wheat (Triticum aestivum L.). Internat. J. Plant Sci., 12 (2): 173-180, DOI: 10.15740/HAS/IJPS/12.2/173-180.

Article chronicle : Received : 19.04.2017; Revised : 11.05.2017; Accepted : 29.05.2017

\section{MEMBERS OF THE RESEARCH FORUM}

Author to be contacted :

MANISHA SAINI, Department of Genetics and Plant Breeding, Chandra Shekhar Azad University of Agriculture and Technology, KANPUR (U.P.) INDIA

Address of the Co-authors:

SHWETA, Department of Genetics and Plant Breeding, Chandra Shekhar Azad University of Agriculture and Technology, KANPUR (U.P.) INDIA 